\title{
TRANSISI CHINA TERHADAP EKONOMI GLOBAL: INTERNASIONALISASI DALAM PERSPEKTIF PEMBANGUNAN MODEL CHINA DAN DINAMIKA REGIONAL
}

\author{
Muhammad Faizal Alfian \\ Departemen Hubungan Internasional, Universitas Diponegoro \\ Email : muhammadfaizalalfian@lecturer.undip.ac.id
}

\begin{abstract}
ABSTRAK
Pada masa reformasi, faktor ekonomi telah menjadi kekuatan pendorong di belakang pertumbuhan dan pembangunan China. Untuk menjaga keberlangsungan ekonomi secara berkelanjutan, China telah merubah orientasi besar dengan menghadirkan model pembangunan kepada negara lain dengan proyek Belt and Road. Arikel ini bertujuan untuk merumuskan tawaran pembangunan China dengan memaparkan beberapa instrument pembangunannya. Untuk mengamati transisi China terhadap ekonomi global khususnya dalam pembangunan penulis menggunakan pendekatan strategic transition yang diambil berdasarkan kajian terhadap politik luar negeri China. Kemudian penulis menganalisis strategi dengan menerapkan instrument yang digunakan dalam internasionalisasi, serta mengkaji dalam beberapa regional terutama di Asia Tenggara dan Asia Selatan. Berdasarkan analisis data, penulis menemukan bahwa dalam transisi ke dalam ekonomi internasional China telah menggunakan beberapa instrumen yaitu: inisiasi Belt and Road sebagai proyek pembangunan serta instrument lembaga keuangan.
\end{abstract}

Kata Kunci: Pembanguan China, Internasionalisasi Ekonomi, Strategi Transisi

\begin{abstract}
In the economic reformation, Economic factor has been driving force power behind the rapid development of China. To maintain economic sustainability, China change their orientation presenting a development model to other countries with a Belt and Road Initiative. This article aims to formulating China's development offer by describing several development instruments. Observing China's transition to the global economy especially for development, the author uses a strategic transition approach, which is taken based on studies of China's foreign policy. The authors is analyzed strategy by applying instruments in internationalization, as well as studying in several regions, especially in Southeast Asia and South Asia. Based on data analysis, the authors found that China has used several instruments in the transition to the international economy, namely: the initiation of the Belt and Road as a development project and instruments of financial institutions.
\end{abstract}

Keywords: China Development, Economic Internationalization, Transition Strategy

\section{PENDAHULUAN}

Dalam beberapa dekade terakhir, China telah menjadi Negara yang mampu masuk dalam Negara berpengaruh di tatanan politik global. Sebagai Negara industrialisasi maju, kebijakan luar negeri China mendominasi beberapa regional dengan strategi yang sangat proaktif di berbagai regional Afrika dan Asia. Peningkatan kebijakan luar negeri yang pro aktif tersebut mengindikasikan kepentingan dan kekuatan China juga meningkat (Wang, 2005). Dorongan peningkatan aktivtas politik dalam tatanan global terjadi Pasca Perang Dingin dengan 
membangun berbagai kemitraan (Cheng, 2002), China mampu mengubah tatanan politik dan ekonomi dunia dengan hadir sebagai salah satu Negara yang berpengaruh diantara Negaranegara Major Power lainnya. Kekuatan politik dan ekonomi menjadi sumber politik internasional dan berhasil menantang dominasi negara barat dibeberapa benua. Secara khusus dalam pembangunan China telah meningkat secara signifikan yang dapat mendorong negaranegara barat mulai mengakui kehadiran China dalam beberapa regional. Di Afrika, investasi asing China telah meningkat mulai secara fundamental membentuk kembali lanskap fisik dan politik di benua tersebut (Tiboris 2019). Bantuan China dan bentuk keterlibatan ekonomi meningkat secara tajam di Afrika dan berpotensi menjadi mitra dagang terbesar di benua Afrika, melampaui Inggris dan Amerika Serikat. Di Asia Selatan dan Asia Tenggara, China mengagas suatu pembentukan kerjasama pembangunan Belt and Road dan telah bergabung dalam beberapa kemitraan strategis dengan organisasi regional.

Kebangkitan China dalam politik luar negeri menimbulkan banyak pertanyaan, apakah aktivitas China dapat menjadi ancaman bagi negara-negara berkembang? Bagaimana pengaturan sistem internasional kehadiran China dan pengaruh Amerika Serikat, Jepang dan India? Pollack and Yang (1998) identifikasi atas ambisi moderenisasi militer oleh elit kemanan China, dan kebasenan norma keamanan regional secara luas, serta kesepemahaman terhadap potensi rivalitas dapat menghasilkan kecemasan bagi negara kecil. Beberapa pemikir menyimpulkan bahwa Politik luar negeri China cenderung asertif (Swaine and Fravel 2011; Johnston 2013). China menerapkan kebijakan militer dan diplomatik yang keras, seringkali memaksa, dan diplomatik dalam beberapa kasus (Johnston 2013), sedangkan dalam beberapa isu China terlihat sangat mencoba untuk membangun kerjasama dalam pembangunan. Sedangkan beberapa pengamat lain mengkonfirmasi kebangkitan China merupakan kebangkitan yang damai (Qingguo 2005; Zhang 2015; Wang 2005). Untuk memperkuat klaim kebangkitan damai, China menerbitkan dua white paper kebijakan luar negeri dengan tema pembangunan damai, masing-masing pada tahun 2005 dan 2011, untuk secara resmi menyatakan komitmennya terhadap kebijakan luar negeri sebagai Peaceful Development (Information Office of the State Council of PRC).

Perdebatan tersebut membawa penulis dalam proses pemahaman mengenai kategorisasi tujuan utama politik luar negeri China dalam perspektif internasional. Lebih jauh, artikel ini bertujuan untuk mengamati internasionalisasi politik luar negeri China dalam beberapa kajian regional dengan membentuk pola yang memungkinkan dalam pembangunan yang di inisiasikan oleh China. Dengan mengamati pola politik luar negeri di beberapa regional 
selanjutnya tulisan ini mencari pola dalam pembangunan internasional yang digagas oleh China.

Proses pertumbuhan ekonomi yang cepat mendorong China menjadi negara ekonomi terbesar kedua di dunia telah menunjukkan dengan jelas menempatkan pembangunan ekonomi sebagai bagian kunci dari pembangunan. Namun, dengan meningkatnya tantangan eksternal dan sosial membenarkan aktivitas China dalam Pembangunan Internasional melalui kebijakan go beyond the borders. Konseptualisasi pembangunan China dalam tulisan ini berusaha untuk mengamati pembangunan yang dijalankan China secara internasional menggunakan fitur pelembagaan internasional melalui instrument pembangunan ekonomi. Pengamatan yang penulis terhadap praktik pembangunan di beberapa regional yang dihubungkan dengan kepentingan ekonomi.

\section{KERANGKA ANALISIS}

Kebangkitan China meningkatkan tantangan ekonomi dan lingkungan bagi sistem global (Fu, 2012). Dengan pertumbuhan ekonominya yang cepat dan integrasi yang mendalam ke dalam sistem global menjadi jalan terbaik dalam menjaga keberlanjutan kemajuannya. Para pemimpin Tiongkok melihat 20 tahun pertama abad ke-21 sebagai periode penting yang dapat menjadi peluang strategis bagi Cina, di bawah kepemimpinan Hu Jintao telah memilih jalan baru menuju kebangkitan damai dalam konsep 'Peaceful Rise' (Li and Worm, 2011). Pasar China yang luas dan potensi bisnis, China menawarkan peluang dunia untuk perdagangan dan investasi, sehingga menghasilkan kekayaan. Tantangan ekonomi antara lain meningkatnya persaingan dari ekspor barang dan jasa serta impor sumber daya alam (Fu, 2012). Pendekatan 'adaptif' untuk meningkatkan kepemimpinan Tiongkok dalam globalisasi. Penginkatan tersebut menjadi indikasi bahwa China telah beralih dalam sistem ekonomi 'open door policy' kearah transisi kearah yang lebih luas yaitu lingkup global.

Beberapa pemikir menyimpulkan bahwa transisi ke sistem global merupakan satu paket kebijakan keterbukaan yang dilakukan dalam reformasi ekonomi. Menurut, Berslin (2013) membagi proses reformasi ekonomi China kedalam empat tahap yaitu: unlocking the door, from permitting to facilitating, 1986-92, accelerating opening, 1992-9, dan joining the WTO 1999. Fase pertama yaitu membuka interaksi dengan ekonomi internasional dengan membuka SEZ yang memicu secara gradual pembukaan wilayah investasi baru. Fase kedua ditandai dengan muncul 'twenty-two regulations' peraturan ini menciptakan lingkungan yang lebih 
menguntungkan bagi investor asing termasuk biaya yang lebih rendah untuk tenaga kerja dan sewa, potongan pajak untuk eksportir, dan memungkinkan perusahaan asing untuk mengubah keuntungan terbatas yang diperoleh dalam RMB menjadi devisa dan mengembalikan keuntungan. Sedangkan fase ketiga adalah akselerasi keterbukaan dengan membangun rezim ekspor internasional yang liberal yang tetap menerapkan rezim perdagangan domestik yang relatif tertutup dan terlindungi untuk mendukung produksi, keuntungan, dan tenaga kerja. Fase keempat bergabung dengan WTO sebagai perubahan orientasi untuk menuju transisi masuk kedalam rezim Free Trade.

\section{Figur 1. Model Transisi Sistem Ekonomi Global}

\begin{tabular}{ccc} 
Open Door & Going Beyond \\
\cline { 2 - 2 } Policy & Strategic Transition & the Border
\end{tabular}

Transisi China kedalam ekonomi global dan pembangunan tidak merujuk pada pendekatan barat. Strategi transisi ini ditandai dengan bergabungnya China ke dalam WTO yang bertujuan sebagai komitmen China dalam pembangunan Internasional. Tentunya hal tersebut tidak terlepas pada kepercayaan bahwa China memiliki kepentingan ekonomi yang sangat besar untuk memperluas perdagangannya. Transisi China kedalam ekonomi Internasional ditandai dengan semakin banyaknya integrasi China dalam rezim seperti ASEAN Free Trade Area, BRICS, dan lainnya. Dimensi penting dari porses transisi adalah bahwa Beijing dengan memperluas hubungan perdagangannya dengan berbagai negara, baik secara bilateral atau multilateral, sambil mempertahankan stabilitas ekonomi domestiknya. Strategi transisi juga dapat dilihat dengan jumlah strategic partnership yang dibangun oleh China (Asgarkhani, Ghahramani, and Hajat 2019).

Salah satu strategi dalam transisi ini adalah sebagian besar sebagai produk padat karya terutama dalam intensitas teknologi ekspornya. Pada tahun 2007, 30 Persen dari ekspor manufaktur China diklasifikasikan sebagai teknologi tinggi dalam database perdagangan UNCTAD (Fu, 2012). Ini sebagian karena sebagian besar ekspornya didasarkan pada komponen yang diimpor dari negara tetangga di Asia yang lebih maju seperti Jepang. Dalam volume absolut, pada tahun 2007 Cina melampaui ekspor barang dagangan Amerika Serikat Serikat, dan pada tahun 2009 melampaui Jerman untuk menjadi pengekspor barang dagangan terbesar di dunia (Fu, 2012). 
Integrasi Cina memiliki kebebasan tertentu dan memiliki perbedaan dengan pendekatan negara-negara lain dalam transformasi ekonomi terencana dan ekonomi pasar yang tidak dipaksa oleh krisis politik (Perkins 1994; webber 2014). Elemen penting pembangunan China pengaturan marketisasi dan arus perdagangan atau investasi. Indikator penting dalam ekonomi China dalam terminologi pembukaan 'Duiwai Kaifang' adalah bagaimana China harus membiarkan membuka pintu terhadap negara lain dan bagaimana China keluar dengan mempromosikan produk 'Made in China' - ekspor - untuk mendapatkan mata uang asing. Transisi dari proses pertumbuhan dalam negeri menuju 'outward looking' (Chen and Wolf 2001) yang mengamati pertumbuhan China dimana dalam reformasi merupakan proses berkelanjutan, sehingga pertumbuhan ekonomi terus berjalan. Untuk menjaga keberlangsungan ekonomi dan tujuan ekonomi-politik, Belt and Road Initiative menjadi instrument utama dalam transisi ini. Selain itu untuk menjaga berjalannnya proyek ini, China juga terus berupaya mempromosikan pembentukan keuangan untuk mempermudah akses modal bagi negara yang masuk dalam proyek besar Belt and Road.

\section{METODE PENELITIAN}

Metode yang digunakan dalam penelitian ini adalah metode kualitatif dengan pedekatan analytical narrative. Pendekatan analytical narrative bertujuan untuk menemukan kesimpulan dari narasai-narasi yang ada dalam perkembangan dan dinamika dalam fenomena dalam hubungan internasional dengan menggunakan teori, sehingga penelitian ini diarahkan pada narasi berupa studi regional penerapan ekonomi politik China. Sedangkan, sumber data diperoleh studi kepustakaan serta dokumen-dokumen yang terkait dengan pembahasan. teknik pengumpulan data dengan menggunakan tinjauan litelatur dengan mencari sumber data yang berhubungan dengan subjek dalam penelitian. Teknik analisis data dalam penelitian ini dimulai dengan pengumpulan data, penyajian data, penyesuaian data dengan literatur yang terkait, penarikan kesimpulan.

\section{PEMBAHASAN}

\section{Instrumen Internasionalisasi Pembangunan China Gagasan Proyek Pembangunan Internasional}

Konten kebijakan luar negeri China termasuk inovasi dan ide tentang bagaimana China menjadi negara unggulan di Asia dalam jangka pendek maupun panjang. Dimana jangaka pendek prioritas pencapaian Partai Komunis China (PKC) pada tahun 2020 menyelesaikan 
pembangunan masyarakat yang dapat memakmurkan masyarakat (xiaokang shehui), dan jangka panjang tercapai pada tahun 2049, untuk mewujudkan negara sosialis modern yang sejahtera, kuat, demokratis, beradab dan harmonis (Callahan, 2016). Menurut Partai Komunis (Roy, 2019), China pada dasarnya adalah negara yang cinta damai, berorientasi pertahanan, non-ekspansionis yang tidak berbahaya dalam beberapa situasi. Selain itu, Xi Jinping juga menyebut 'Tidak peduli seberapa kuat ekonominya tumbuh, China tidak akan pernah mencari hegemoni, ekspansi, atau lingkup pengaruh' (Roy, 2019). Akan tetapi, politik luar negeri China bersebrangan dengan pernyataan tersebut, dengan kekuatan militer yang cukup besar mampu melakukan konfrontasi di regional Asia Tenggara dan mengklaim wilayah laut China Selatan merupakan wialayah teritorialnya. Tindakan assertif ini menjelaskan bahwa tekad untuk menang dalam sengketa perbatasan, melalui penggunaan kekuatan militer diperlukan (Roy, 2019).

Pemerintahan Xi Jinping memfokuskan pada peripheral diplomacy, yang digunakan untuk pengelolaan hubungan di pinggirannya karena meningkatnya ketegangan dengan negaranegara tetangga: terutama dalam perselisihan maritim di Laut Cina Timur dan Selatan (Callahan, 2016; Asgarkhani, Ghahramani, and Hajat 2019). Xi mengemukakan bahwa China perlu membangun hubungannya dengan tetangga sesuai dengan prinsip persahabatan, ketulusan, dan timbal balik. Menurut Callahan (2016) BRI merupakan salah satu inisiatif yang didorong oleh dua peristiwa penting yaitu perlambatan ekonomi pasca krisis 2008 dan strategi poros AS di Asia. Hal ini sejalan dengan penelitian Wang yang menyatakan bahwa dampak krisis keuangan global tahun 2008 dan setelah mengalami pertumbuhan kecepatan tinggi, ekonomi China telah melambat sejak 2012 dan memasuki keadaan pertumbuhan normal (Trading Economic, 2020). Selain itu, terdapat tantangan yang besar bagi China dalam menghadapi politik internasional Amerika Serikat di Asia Pasifik dengan kehadiran Trans Pacific Partnership (TPP) dan kebijakan US Pivot to Asia. China menganggap bahwa kedua strategi tersebut sebagai pergeseran kepentingan AS menuju Asia Timur, serta penguatan pengaturan keamanan bilateral, meningkatkan kekhawatiran China tentang ancaman jangka panjang terhadap kedaulatannya. Kehadiran, AS di Asia menjadi latar belakang China meninggalakan kepentingan geopolitik yang besar di Laut China Selatan dan Timur, sehingga BRI dalam bukanlah untuk menantang AS di Laut Cina Timur dan Selatan. Sebaliknya, BRI akan bekerja untuk membangun kepercayaan timbal balik strategis karena AS dan China benarbenar memiliki banyak kepentingan bersama di Eurasia (Callahan, 2016).

Xi Jinping, memutuskan untuk mengejar strategi kontinental dan maritime daripada 
mengejar perdebatan kepentingan dengan AS. BRI menegaskan bahwa China dapat menggunakan keunggulan komparatif tidak hanya untuk membantu negara lain, tetapi juga untuk mengatasi masalah kelebihan kapasitas industri konstruksi infrastrukturnya dan juga memungkinkan China untuk melakukan diversifikasi investasi cadangan devisa (Callahan, 2016). Tentunya proyek continental yang sejalan dengan diplomasi peripherial sangat tetap dilakukan dengan hadirnya BRI sebagai alat politik dan ekonominya. Hal ini didukung dengan kepentingan kebutuhan energi dalam negeri untuk merangsang kelangsungan industri di China, bahkan ketergantungan China terhadap energi impor telah melampaui Amerika Serikat, dan menghadapi tantangan besar untuk memastikan pasokan energy (Yong, 2016) .

Berdasarkan penjelasan tersebut BRI lahir dari dua peristiwa yang bersamaan yaitu ekonomi dan satu strategi. Setelah Xi Jinping naik ke posisi Wakil Presiden RRC pada Maret 2008, China mulai merasakan pengaruh dari krisis keuangan global. Pada tahun 2010, pemerintahan Obama mengumumkan kebijakan porosnya Asia Pasifik. Kedua peristiwa ini menyebabkan elit China menilai kembali prospek pembangunan ekonomi dan lingkungan strategis eksternalnya. BRI dapat dipahami sebagai upaya untuk merespons tantangan yang meningkat di kedua domain tersebut. Sejalan dengan penelitian Callahan menurut, Lily Ouyang motivasi China menginisiasikan Belt and Road adalah dilatarbelakangi oleh; Meningkatkan keamanan di Eurasia, Penyesuaian terhadap strategi Pivot Asia AS, Memperoleh sumber daya alam dan rute perdagangan yang penting secara strategis dan penetapan Community of Interest di bawah kepemimpinan China (Ouyang 2017).

Dengan sebutan 'The Miracle of Asia', pada masa kebangkitannya, China tidak hanya memperbaiki kondisi domestik tetapi juga telah memulai kebijakan luar negeri yang aktif, seperti China Foreign Aid to Africa. Bantuan luar negeri ke Afrika merupakan langkah awal yang sangat strategis untuk terlibat aktif dalam politik internasional, sehingga memeperoleh banyak pencapaian dalam beberapa aspek (Addis dan Zuping, 2018: 357-358), terutama terpenuhinya kebutuhan sumber daya dan energi. Menaruh kepentingan terhadap Afrika tersebut kemudian ditindak launjuti dengan berbagai kebijakan luar negeri yang sangat aktif lainnya.

Pada tahun 2003, Lembaga Dewan Negara China menyatakan program energi pertamanya yang berjanji untuk memberikan dukungan diplomatik dan militer serta jaminan kepada perusahaan minyak untuk kegiatan bisnis di luar negeri (Wilson 2017). Selain itu, setelah melakukan investasi asing yang didanai negara dalam jumlah yang lebih besar, terlibat 
dalam program diplomasi sumber daya yang lebih aktif. Namun ini hanya menunjukkan bahwa pemerintah telah mendorong strategi yang lebih jauh. Skeptisme hadir terhadap kepemimpinan China dalam pembangunan di Afrika mempengaruhi kontestasi politik pembangunan selanjutnya. Hubungan China-Afrika yang dibangun melalui bantuan luar negeri menjadi miniatur kecil untuk menaruh kepentingan yang besar pada interaksi internasional. China terlibat dalam beberapa ketegangan keamanan multilateral di wilayah Asia-Pasifik, khususnya sengketa wilayah maritim yang saat ini semakin meningkat di Laut Cina Timur dan Selatan (Wilson 2017).

Dengan kepentingan dalam dunia internasional yang meningkat yang berbanding lurus dengan peningkatan kebutuhan terhadap sumber daya dan energi, China kembali mengambil langkah besar dengan menginisiasikan pembangunan fasilitasi perdagangan, dengan mempromosikan Belt and Road Initiative (BRI). BRI menjadi grand strategi geopolitik dalam politik internasional, melihat bahwa inisiatif pembangunan tersebut mencakup berbagai regional dengan interaksi politik internasional yang sangat kompleks (Blanchard and Flint, 2017). Pembangunan ini berkontradiksi dengan kebijakan represif terhadap Negara-negara tetangganya, dimana hadir sebagai Negara yang memberikan bantuan dengan menjali kemitraan di berbagai regional.

Di kawasan Asia Selatan termasuk di Samudera Hindia, BRI menghadapi tantangan geopolitik dan geostrategik. Kehadiran China di Asia Selatan berimpilkasi terhadap rivalitas India-China yang cenderung kompetisi dalam memperoleh pengaruh di regional tersebut. Kekhawatirannya India terhadap proyek BRI secara lebih luas, inisiatif yang didanai China untuk memperluas pengaruh strategis. Kedua negara telah mengklaim status kekuasaan regional, yaitu posisi dominan dengan menaruh kepentingan. India telah menggunakan strategi bilateral dan multilateral yang untuk mengejar peran kepemimpinan regionalnya di Asia Selatan (Wagner 2016). BRI membuat rivalitas India-China semakin kompleks dengan tumbuhnya pengaruh China di Asia Selatan sehingga meninmbulkan pertanyaan 'siapa kekuatan regional'.

Disamping itu pendanaan proyek di sub-wilayah berbading lurus dengan kebutuhan negara-negara Asia yang mencari dana untuk pembangunan infrastruktur, namun timbul kecurigaan bahwa penerimaan proyek tersebut dilakukan atas pengaruh geopolitik China. BRI perlu diperdebatkan apakah kegiatan China di regional menudukung perkembangan ekonominya sendiri dan seberapa jauh mengejar kebijakan dominasi dan 'Encirclement' terhadap kekuatan ketiga dari negara berpengaruh di beberapa regional. Ditengah munculnya 
presepsi-presepsi untuk memuluskan inisiasi tersebut, China dibawah pemerintahan Xi Jinping memfokuskan pada peripheral diplomacy, yang digunakan untuk pengelolaan hubungan di pinggirannya karena meningkatnya ketegangan dengan negara-negara tetangga: terutama dalam perselisihan maritim di Laut Cina Timur dan Selatan (Callahan, 2016). Promosi BRI menjadi menarik untuk dikaji mengingat China dalam mertahankan kepentingan energinya, menggunakan perangkat konfrontasi wilayah persengketaan serta memberikan jaminan bantuan militer dengan mitranya dan secara bersamaan menggunakan pola kemitraan dalam pembangunan.

\section{Instrument Lembaga Keuangan}

Asian Infrastructure Investment Bank (AIIB), AIIB didirikan pada bulan Oktober 2013, selama kunjungan berturut-turut ke negara-negara di Asia Tenggara, presiden China Xi Jinping dan Perdana Menteri Li Keqiang mengajukan proposal untuk mendirikan Asia Infrastructure Investment Bank. Proposal ini mendapat dukungan luas. Pada tanggal 24 Oktober 2014, para menteri keuangan dan perwakilan resmi dari 21 negara anggota pendiri yang pertama, termasuk China, India, Thailand dan Kazakhstan, menandatangani sebuah kesepakatan di Beijing, dan bersama-sama memutuskan untuk mendirikan Asia Infrastructure Investment Bank (AIIB) yang menjadi lembaga keuangan terbuka, antar pemerintah dan multilateral. Operasinya akan mengikuti prinsip keterbukaan, transparansi dan efisiensi, dan ini terutama bertujuan untuk mendukung pembangunan infrastruktur di negara-negara Asia. Walaupun memengang prinsip transparansi AIIB tetap menjadi bank multilateral yang didominasi oleh China, dimana China memiliki total pemungutan suara lebih dari $26 \%$ karena kontribusinya sebesar 29,78 miliar US Dollar (Hong, 2017). China adalah investor terbesar di AIIB dan pemegang saham terbesarnya. Seperti yang tertulis di kesepatakatan tertulis (AOA), setidaknya 75\% dari jumlah suara diperlukan untuk mengubah AOA, menyesuaikan modal saham anggota, meningkatkan modal dasar bank dan melakukan perubahan besar lainnya. Dengan demikian, China memiliki hak veto de facto di bank. Asian Infrastructure Investment Bank (AIIB) dan Belt and Road Initiative kemungkinan besar akan membentuk kembali geografi ekonomi di wilayah yang terkena dampak dan dengan demikian memberikan pengaruh pada lanskap ekonomi global

Untuk mendorong peningkatan investasi China menirikan Silk Road Fund yang merupakan badan usaha milik pemerintah China di negara-negara di sepanjang proyek BRI. Pemerintah China menjanjikan dana sebesar 40 miliar US Dollar untuk pembentukan dana 
investasi yang ditetapkan pada 29 Desember 2014 (Das, 2017). Selain itu, lembaga lain yang terlibat dalam pembangunan dan proyek China adalah China Export-Import Bank. Bank ini merupakan bank milik negara China yang mengambil inisiatif dalam membiayai BRI untuk memberi kompensasi. Pada bulan September 2015, telah membiayai 2057 proyek di 49 negara. 10 Bank Pembangunan China juga telah membiayai lebih dari 400 proyek di 48 negara pada Agustus 2015 (Aoyama, 2016).

Belt and Road Forum (BRF), merupakan platform atau wadah bagi negara untuk berkonsultasi. Pembentukan platform BRF membantu mencapai penggunaan produk publik yang wajar dan efisien, sehingga dapat mencapai komunikasi, konsultasi dan koordinasi melalui BRF dan mengurangi biaya transaksi dan meningkatkan efisiensi kerja sama. Forum tersebut memiliki tujuan besar yaitu dalam merencanakan keseluruhan kerangka kerja untuk membangun Belt and Road, mengembangkan kebijakan dan rencana aksi yang relevan, menegosiasikan dan memecahkan masalah utama yang timbul dalam pengembangan bersama mereka, sehingga dapat meningkatkan efisiensi kerja sama.

\section{Dinamika Politik di Regional Asia Pasifik}

Presepsi terhadap ancaman menjadi jalan keluar untuk memperkuat posisi China dengan membangun kedekataan secara politik dengan negara mitra untuk menghalau ancaman baik lingkup ekstrenal dan internal. Ancaman besar China terutama untuk menghalau strategi Amerika Serikat di Asia Pasifik dengan kebijakan 'Look East'-nya. Kekawatiran China terhadap aktivitas militer AS dengan negara tetangga serta membatasi pergerakan lebih jauh Amerika Serikat di Asia Pasifik (Roy, 2019). Presepsi tersebut menghasilkan proyeksi China lebih besar terhadap perluasan pengaruh untuk menangkal tensi di regional. Perluasan pengaruh tidak hanya membuat India sebagai rival China perlu melihat kepentingan geopolitik atau bahkan geostrategis, karena beberapa sumber mengklaim pendeketan kemitraan militer terjadi di Asia Selatan. Departemen Pertahanan AS, mengklaim bahwa:

The Indo-US Defence Joint Working Group, meeting at New Delhi in April 2007, for example, is reported to have discussed '(China's) growing naval expansion in the Indian Ocean (and its) rapidly increasing military and maritime links with countries ... such as Myanmar, Bangladesh, Sri Lanka. . ' (Athwal, 2008).

Laporan menyebutkan bahwa China merencanakan membangun pangkalan militer,

pelabuhan dan fasilitas lain di wilayah yang ditargetkan untuk mencapai tujuan strategis (Athwal 2008). Indikasi tersebut diperkuat dengan data bahwa Asia Selatan sekarang 
merupakan pasar ekspor senjata China dimana pada Tahun 2015 Pakistan menerima 35\% ekspor senjata, dan Bangladesh 20\% (Freeman, 2018). Maka dari itu, geostrategi yang berhubungan dengan pendekatan terhadap peningkatan kerjasama militer khususnya di Samudera Hindia disebut sebagai Strategi String Perals. Strategi String Pearls menjadi grand geostrategis jangka panjang bagi China untuk memperluas pengaruh wilayah Samudra Hindia, untuk menghilangi hambatan baik secara ekonomi maupun militer.

Sehubungan dengan kehadiran China dalam geopolitik Asia Selatan, inisiasi Belt and Road mempengaruhi tensi politik di Asia Selatan. Tentunya, BRI menejadi inisiasi proyek yang baik untuk perkembangan ekonomi di Asia, tetapi hambatan terbesar adalah keyakinan terhadap proyek tersebut. Indian Security and Foreign Affairs mengkritik BRI dengan alasan bahwa hal itu memungkinkan proyeksi kekuatan militer China, walaupun dapat menguntungkan secara ekonomi (Freeman, 2018). Bahkan timbul kecurigaan bahwa pelabuhan dikembangkan dan dikelola oleh China di Pakistan, Sri Lanka, Bangladesh dan Maladewa, serta Djibouti, dipandang sebagai batu loncatan militer untuk melawan dominasi India di wilayah Samudra Hindia (Lu, 2019).

Kemitraan Pakistan-China merupakan eksistensi jangka panjangnya di Asia Selatan. Kemitraan China-Pakistan terwujud dalam koridor China-Pakistan Economic Corridor (CPEC merupakan koridor BRI di Asia Selatan), yang berimplikasi terhadap perluasan geostrategic China di Regional tersebut. Hal ini didukung dengan asumsi bahwa pembangunan Pelabuhan di Gwadar, Pakistan memungkinkan China untuk memantau jalur komunikasi laut yang berdekatan dengan Selat Hormuz (Chung, 2018). Selat Hormuz merupakan wilayah yang merupakan jalur perdagangan dan jalur militer Timur Tengah sehingga setiap negara memiliki kepentingan yang sangat besar di wilayah tersebut. Pada Mei 2017, Pembicaraan pertahanan dan keamanan antara kedua negara menegaskan kerja sama pertahanan melalui penjualan kapal selam China, pengembangan pesawat tempur dan kapal patroli, serta pembentukan Pakistan Maritime Security Agency (PMSA) (Freeman, 2018). Dengan demikian, Axis China-Pakistan bertujuan memperkuat kemampuan Pakistan; dan menjaga keefektifan ancaman yang dapat ditimbulkan baik dari ancaman pemberontakan (internal) ataupun ancaman perang (eksternal). Kedekatan antara China dengan Pakistan tersebut memperjelas ancaman eksternal jangka panjang di Samudera Hindia dan mempertegas kekuatan ekonomi dan politik di jalur tersebut.

Bergeraknya arah pengaruh India di Asia Selatan bukan hanya disebabkan oleh axis China-Pakistan tetapi juga pengaruhnya yang semakin menguat dengan kerjasama ekonomi 
China-Sri Lanka. Motif China cukup jelas untuk memperkuat ikatannya Sri Lanka yaitu akses terhadap minyak, pelabuhan, dan jalur ke Samudra Hindia (Sahoo, 2013: 112). Setelah kemenangan pemilihan Presiden Rajapaksa pada 2005, China mengintensifkan hubungan ekonominya dengan Sri Lanka, yang diikuti tahun 2006 -2008 bantuan luar negeri China meningkat melampaui Jepang (Wagner 2016). Akan tetapi, terpilihnya Rajapaksa dan kedekatannya terhadap China, membuat pengaruh India tergerus oleh kepentingan China. Lebih dari 50\% dana yang diterima oleh Sri Lanka dari luar negeri untuk proyek konstruksi dan pengembangan, sejak Presiden Mahinda Rajapaksa berkuasa, berasal dari China (Raman, 2011). Tergerusnya pengaruh India semakin memperkuat posisi China dengan membangun dua proyek pembangunan pelabuhan yaitu Proyek Colombo Port City dan Proyek Pelabuhan Hambantotat, dalam proyek MSR. Selain itu, China berinvestasi di pembangkit listrik tenaga batu bara, mengembangkan zona ekonomi khusus, dan memperoleh hak untuk mengeksplorasi minyak di Teluk Mannar (Ayres and Mohan 2009). Hubungan Tiongkok dengan Sri Lanka tidak menguntungkan India karena dapat berimplikasi terhadap geo-strategis di India. Menurut Shrivastava (Chung, 2018) dalam jangka panjang China memiliki rencana untuk menggunakan pelabuhan sebagai stasiun pengisian bahan bakar dan dok untuk angkatan lautnya, berpatroli di Samudra Hindia untuk melindungi pasokan minyak China dari Timur Tengah. Pengaruh China semakin menguat dengan posisi Rajapaksa dengan kesediaan China untuk memasok senjata dan amunisi modern dan berat kepada Angkatan Bersenjata Sri Lanka dalam upaya menghilangkan eksistensi pemberontak Liberations Tigers of Tamil Eelam (LTTE). Di samping hubungan pembangunan infrastruktur dan peningkatan kerjasama ekonomi, hubungan China-Sri lanka dimasa pemerintahan Rajapaksa tidak berbeda dengan Pakistan yaitu elemen kemitraannya adalah teknologi dan akses militer penting bagi strategis China.

Selain menjali kemitraan dengan Pakistan dan Sri Langka, prioritas terbesar China untuk memperkuat eksistensinya di Asia Selatan adalah dengan mengembangkan potensi Nepal. China menjalin kerjasama dengan Nepal dengan infrastruktur jalan dan jalur kereta api yang menghubungkan antara Tibet, Nepal, India, Bangladesh dan Myanmmar. Tentunya, menjalin kerjasama dengan Nepal merupakan strategi yang sangat tepat bagi China, karena dominasi kepemimpinan Maoist di Nepal yang dimulai masa Prachanda serta terpilihnya K.P Oli sebagai Perdana Menteri. Hal ini didukung dengan pernyataan Zheng Xianglin China Ambassador untuk Nepal, pada 5 Augustus 2008 yang menyatakan 'Nepal is situated in a favorable geographical position in South Asia, and is a passage linking China and South Asia' (Raman, 2011). Penelitian Raman (2011) juga menunjukkan data bahwa kerjasama militer 
telah dibangun Nepal-China sejak 1998, ketika Militer Nepal mengirim pasukannya ke Universitas Militer China, selanjutnya dalam tahun 2007 sekitar 21 Prajurit dan Petugas Militer Nepal latihan di China. Kedekatan tersebut mengindikasikan bahwa Nepal hadir sebagai intrumen penguatan eksistensi China di Asia Selatan serta menjadi penghalang kepentingan kelompok pemberontak Tibet yang selama ini mengancam kestabilan politik di perbataasan China-Nepal.

Prioritas selanjutnya bagi China adalah dengan menjalin kerjasama pembangunan infrastruktur dengan Bangladesh dalam koridor BCIM yang menghubungkan BangladeshChina-India-Myanmmar konektivitas moderenisasi jalan dan rel kereta api. China memulai hubungan diplomatic dengan Bangladesh pada Tahun 1975, dalam periode junta Militer, dan kerjasama pertahanan dimulai pada tahun 2002 (Wagner 2016). Setelah kerjasama militer terjalin, perusahaan China mulai menginvestasikan proyek teramasuk pembangunan Pelabuhan Chittangong dan proyek jalan raya yang menghubungkan Bangladesh-Myanmmar. Selain itu, Bangladesh telah memberikan hak eksplorasi untuk China dalam mengembangkan gas alam di Barakpuria (Chung, 2018). China juga menjamin meningkatkan investasi dan mengurangi hambatan perdagangan dengan memberikan akses pasar untuk produk Bangladesh ke pasar China. China juga menjamin memberikan bantuan untuk mengatasi isu keamanan pangan dan keamanan negara dalam mengatasi militansi dan terorisme (Raman, 2011). Melalui bantuan keamanan tersebut, Bangladesh menjadi lokasi strategis untuk pengembangan ekonomi dan militernya. Menurut laporan dalam Penelitian Khurana (2008):

indicated that Bangladesh has been negotiating with China and South Korea to develop its Chittagong military and civilian facilities,... This adds to an earlier report of 2005 that Bangladesh intends to build a second naval base at Chittagong'.

Pembangunan infrastruktur pelabuhan dan jalur darat di Chitanggong memperkuat posisi strategis terhadap akses pasar dan komunikasi militer yang strategis bagi ChinaMyanmmar. Laporan tersebut mengindikasikan bahwa eksistensi China tidak hanya mengedepankan pembangunan ekonomi akan tetapi juga membawa pendekatan militer dalam kerjasama dengan Bangladesh. Walaupun tujuan dari pembangunan pangkalan militer di Chittangong berupa kepentingan untuk melawan kelompok radikal dan terorisme termasuk melindungi jalur perdagangan, akan tetapi laporan tersebut memperkuat argument bahwa kehadiran China di Asia Selatan tidak hanya membawa pengaruh pembangunan. 
Berdasarkan pola kerjasama kemitraan dan hubungan diplomatic China dengan negaranegara di Asia Selatan menunjukkan motif besar, tidak hanya untuk memperoleh akses terhadap energi tetapi juga memperluas pengaruh politik. Dalam beberapa studi kasus diatas menunjukkan bahwa China mengembangkan pola kerjasama dengan memanfaatkan pembangunan infrastruktur termasuk BRI, serta juga membawa isu keamanan bersama dengan bantuan dan kerjasama militer. Disisi keuntungan dalam pembangunan fasilitas perdagangan melalui BRI, terdapat kecurigaan terhadap bantuan dan investasi. Di satu sisi, China menggunakan kekuatan ekonomi untuk membantu pembangunan proyek infrastruktur, Sedangkan di sisi yang lain, China menjalin hubungan militer dengan negara di Asia Selatan tersebut. Maka, strategi 'String Pearls' diartikan sebagai menjalin hubungan kemitraan keamanaan ekonomi dan militer. Upaya untuk membangun infrastruktur maritim di Samudra Hindia memiliki tujuan ganda yaitu: mengatasi kebutuhan pengiriman yang terus berkembang dan membangun pelabuhan yang dapat menjadi pangkalan angkatan laut (Kostecka, 2011). Secara khusus, pelabuhan Gwadar di Pakistan, Chitangong di Bangladesh, dan Hambantota di Sri Lanka menjadi aset militer potensial bagi China (Dixon, 2014).

Kepemimpinan di negara yang lebih kecil di Asia Selatan harus memilih antara kepentingan India dan China, mana yang lebih menguntungkan untuk menjalin kerjasama. Dalam lingkup eksternal berdasarkan studi kasus diatas memperlihatkan bahwa keberhasilan politik luar negeri China adalah dengan membawa presepsi pembangunan sebagai jalan menuju kemajuan ekonomi melalui inisiasi Belt and Road dan presepsi menjaga keamanan bersama melalui peningkatan kerjasama militer. Dalam politik internasional, kerjasama di Asia Selatan belum menunjukkan dampak interdependensi negara mitranya terhadap China akan tetapi kepentingan yang dibawa China dapat membuat rivalitas di Asia Selatan semakin meningkat. Kebijakan luar negeri regionalisme Tiongkok di Asia Selatan lebih banyak dipengaruhi oleh persepsi persaingan geostrategic, sehingga membuat pembangunan ekonomi dan keamanan sebagai saling terkait.

\section{KESIMPULAN}

Dengan pertumbuhan cepat China menghasilkan beberapa inisiatif yang mendorong langkah besar pada transisi China kedalam ekonomi global. Terdapat pola yang sangat jelas terlihat dimana perubahan orientasi dari stabilitas ekonomi domestic menjadi 'go beyond the border' menjadi konten utama transisi ini. Model ini merupakan strategi terpenting bagi China setelah melewati masa reformasi ekonomi Model ini telah memberikan kontribusi besar terhadap status 
Tiongkok saat ini dalam sistem internasional. Beberapa bukti yang terlihat jelas adalah pengembangan inisiatif besar terhadap proyek pembangunan antara benua yang digagas yaitu BRI (Belt and Road Initiatives). BRI memperlihatkan upaya China untuk mempromosikan posisi internasionalnya mengarah pada peran aktif dalam ekonomi internasional, dan sebagai hasilnya, model ekonomi baru dapat lebih memenuhi posisi China dalam sistem internasional.

Ekspansi ekonomi ke dunia luar merupakan agenda terpenting bagai China untuk mengembangkan jejaring konektivitas sehingga lingkungan ekonomi dapat terjaga. Walaupun dalam beberapa kasus kebijakan, China dapat menunjukkan potensinya untuk kepemimpinan ekonomi masa depan. Pengembangan inisiatif adalah instrument utama dalam pembentukan karakter China dalam sistem pembangunan internasional dan menjadi tantangan kemajuan bagi lingkungan internasional.

\section{DAFTAR PUSTAKA}

Addis, A. K. \& Zhu, Z. (2018). Criticism of neo-colonialism: clarification of Sino-African Cooperation and its Implication to the West. Journal of Chinese Economic and Business Studies, 16(4), 357-373.

Aoyama, R. (2016). One Belt, One Road: China's New Global Strategy. Journal of Contemporary East Asia Studies, 5(2), 3-22.

Asgarkhani, A., Ghahramani, M. J., \& Hajat, M. G. (2019). Geoe-conomic Analysis of China 's Foreign Policy. Geopolitics Quarterly, 14(4), 209-233.

Athwal, A. (2008). China India relations territorial imperative. Routledge.

Ayres, A., \& Mohan, C. R. (2009). Power Realignment in ASIA: China, India, and the United States. Sage Publications. http://library1.nida.ac.th/termpaper6/sd/2554/19755.pdf.

Blanchard, J. F. dan Flint, C. 2017. 'The Geopolitics of China's Maritime Silk Road Initiative', Geopolitics, .22(2), 223-245.

Brautigam, D. (2010). The Dragon's Gift: The Real Story of China in Africa. Oxford University Press.

Callahan, W. A. (2016). China's Asia Dream: The Belt Road Initiative and the new regional order, Asian Journal of Comparative Politics 1(3), 226-243.

Chen, S., \& Wolf, C. (2001). China, the United States, and the Global Economy. RAND.

Cheng, J. Y. S. and Zhang W. (2002). Patterns and Dynamics of China's International Strategic Behaviour, Journal of Contemporary China, 11:31, 235-260.

Chung, C.P. (2018). What are the strategic and economic implications for South Asia of China's Maritime Silk Road initiative?, The Pacific Review, 31(3), 315-332.

Dixon, J. (2014). From "Pearls" to "Arrows": Rethinking the "String of Pearls" Theory of China's Naval Ambitions, Comparative Strategy, 33(4), 389-400.

Freeman, C. P. (2018). China's 'regionalism foreign policy' and China-India relations in South Asia. Contemporary Politics, 24(1), 81-97.

Johnston, A. I. (2013). How New and Assertive Is China's New Assertiveness?'. International Security, 37(4), 7-48. 
Kostecka, D. J. (2011), Places and Bases: The Chinese Navy's Emerging Support Network in the Indian Ocean. Naval War College Review 64(1).

Khurana, G. S. (2008). China's 'StringofPearls' in the Indian Ocean and Its Security Implications, Strategic Analysis, 32(1), 1-39.

Ouyang, L. (2017). One Belt, One Road and China's Evolution in Foreign Policy and Regional Leadership. In Global Commerce Scholar Thesis.

Pollack, J. D., \& Yang, R. H. (1998). In China's shadow regional perspectives on Chinese foreign policy and military development. In Conference proceedings (Rand Corporation) (pp. ix, 184 p. ;-ix, 184 p. ;). http://library.sfasu.edu/find/Record/818447

Qingguo, J. (2005). Peaceful development: China's policy of reassurance. Australian Journal of International Affairs, 59(4), 493-507. https://doi.org/10.1080/10357710500367299

Roy, Denny, 2019, Assertive China: Irredentism or Expansionism?, Survival, 61(1), 51-74.

Raman B. (2011), China's Strategic Influence in South Asia, Maritime Affairs. Journal of the National Maritime Foundation of India, 7(2), 134-141.

Sahoo, P. (2013). The Growing Dominance of China in South Asia: An Indian Perspective. The International Trade Journal, 27(2), 111-141.

Swaine, M. D., \& Fravel, M. T. (2011). China's Assertive Behavior Part Two. The Maritime Periphery.pdf. 1, 1-29.

Tiboris, M. (2019). Addressing China's Rising Influence in Africa. Chicago Council on Global Affairs, May, 1-14.

Trading Economic. (2020). China GDP Annual Growth Rate Forecast. https://tradingeconomics.com/china/gdp-growth-annual

Wagner, C. (2016). The Role of India and China in South Asia. East-West Center: Asia Pacific Bulletin, 40(4), 307-320.

Wang, F. L. (2005). Preservation, prosperity and power: What motivates China's foreign policy? Journal of Contemporary China, 14(45), 669-694. https://doi.org/10.1080/10670560500206033.

Wilson, J. D. (2017). International resource politics in the Asia-Pacific: The political economy of conflict and cooperation. In International Resource Politics in the Asia-Pacific: The Political Economy of Conflict and Cooperation (Vol. 1). https://doi.org/10.4337/9781786438478.

Yu, H. (2017). 'Motivation behind China's One Belt, One Road Initiatives and Establishment of the Asian Infrastructure Investment Bank', Journal of Contemporary China, 26(105), $.353-368$.

Zhang, J. (2015). China's new foreign policy under xi jinping: Towards 'peaceful rise 2.0'? Global Change, Peace and Security, 27(1), 5-19. https://doi.org/10.1080/14781158.2015.993958. 